\title{
A Multifocal Malignant Fibrous Histiocytoma of the Bone Evolving From Fibrous Dysplasia
}

\author{
Patrick BRÜCK ${ }^{1}$, Sebastian LINDEMAYR ${ }^{2}$, Angelika BÖHME ${ }^{3}$, \\ Lothar BERGMANN ${ }^{4}$, Andreas KURTH ${ }^{5}$ \\ ${ }^{1}$ University of Giessen, Medical Clinic for Hematology and Medical Oncology \\ ${ }^{2}$ University of Frankfurt, Department of Diagnostic and Interventional Radiology \\ ${ }^{3}$ Oncologikum, Schaubstraße 16, 60596 Frankfurt a. M., Germany \\ ${ }^{4}$ University of Frankfurt, Department of Medicine, Hematology and Oncology \\ ${ }^{5}$ University of Mainz, Orthopedic Clinic, Fankfurt, GERMANY
}

\begin{abstract}
Fibrous Dysplasia (FD) is a focal bone lesion occurring sporadically and in hereditary syndromes caused by activating mutations of the $G$ protein alpha subunit. It rarely undergoes malignant transformation. Malignant Fibrous Histiocytoma (MFH) is a sarcoma of soft tissues and may be found as primary sarcoma of the bone or multifocally. Until now only a few cases of malignant transformation of FD into MFH of the bone have been described. We report a case of a 38 year old female with polyostotic FD. Years after the first diagnosis of FD, pain with sudden onset and diminution of force in the left lower limb finally led to the diagnosis of a multifocal MFH of the bone. No response to different chemotherapy schemes was found and the patient deceased shortly after. This is the first described case of a polyostotic FD with malignant transformation into a multifocal MFH of bone. Due to the rarity of this entity and the lack of response to chemotherapy no treatment recommendations can be concluded.
\end{abstract}

Keywords: Multifocal malignant fibrous histiocytoma of the bone, Fibrous dysplasia, Polyostotic

\section{ÖZET}

\section{Fibröz Displaziden Gelişen Kemiğin Multifokal Malign Fibröz Histiyositomu}

Fibröz displazi (FD), G protein alfa altbiriminin aktivasyonu sonucu ortaya çıkan sporadik görülen, genetik geçişli fokal kemik lezyonudur. Malign transformasyonu çok nadirdir. Malign fibröz histiyositoma (MFH), multifokal veya primer kemikte de görülebilen yumuşak doku sarkomudur. FD'nin malign transformasyonla MFH'a dönüşmesiyle ilgili literatürde çok az sayıda vaka bildirilmiştir. Bu raporumuzda polyostotik FD olan 38 yaşında kadın hasta sunulmuştur. Illk tanıdan yıllar sonra ağrı, ve alt ekstremitede kuvvet kaybıyla ortaya çıkan tablo multifocal MFH tanısının habercisi olmuştur. Kemoterapiye cevapsız olması nedeniyle tanıdan kısa süre sonra hasta kaybedilmiştir. Bu vaka raporumuz, polyostotik FD'nin multifokal MFH'a malign transfromasyonunu sunmaktadır. Bu durumun nadirliği ve kemoterapi yanıtsılığı nedeniyleriyle tedavi önerisi sunamamaktayız.

Anahtar Kelimeler: Kemiğin multifokal malign fibröz histiyositomu, Fibröz displazi, Polyostotik 


\section{INTRODUCTION}

Fibrous dysplasia (FD) is a focal osseous disease with monostotic or polyostotic forms that are caused by postzygotical, non-inherited missense mutations of the stimulatory G protein (Gs) alpha subunit within the GNAS complex locus on chromosome $20 .{ }^{1}$ The mutated alpha subunit exhibits a greatly reduced GTPase activity what leads to a prolonged activation of the Adenylyl Cyclase resulting in inappropriate high levels of cAMP thereby leading to increased proliferation and poor differentiation of bone marrow stromal cells. ${ }^{2}$

Clinical symptoms of FD arise from painful bone deformities that are due to iterative fractures or rarely complications such as nerve compression or malignant transformation. Within genetic symptoms like the McCune-Albright syndrome (MAS), some patients present with endocrine dysfunctions (generally precocious puberty) and cutaneous café-au-lait spots. ${ }^{3}$ Diagnosis relies on radiologic examination and histologic findings though these may be unspecific. A firm white fibrous tissue with a rim of sclerotic bone replaces the osseous medullary cavity. Microscopically, the tumour is composed of a randomly distributed array of collagen fibres produced of spindled mesenchymal cells ${ }^{2}$ intermixed with metaplastic, but benign bone. ${ }^{4}$

Primary Malignant Fibrous Histiocytomas (MFH) of bone are sporadically occurring subtypes of malignant osseous lesions though the term MFH is sometimes used to describe neoplastic lesions that cannot be further classified. ${ }^{5}$ Hereditary forms of MFH as in the autosomally dominant inherited Hardcastle syndrome with diaphyseal medullary stenosis and bone malignancy are rare forms of familial neoplasms. ${ }^{6}$ Clinical symptoms of primary MFH are nonspecific like local swelling, pain and pathologic fractures. Radiologic findings include osteolytic lesions with an aggressive growth and subsequent cortical destruction. Extraosseous spread is mostly present.? MFH of the bone is histologically a pleomorphic sarcoma containing both fibroblast- and histiocyte-like elements in varying proportions thus manifesting a range of histologic appearances with five described subtypes. To our knowledge there are only few case reports describing multifocal forms of MFH of the bone. ${ }^{8-11}$

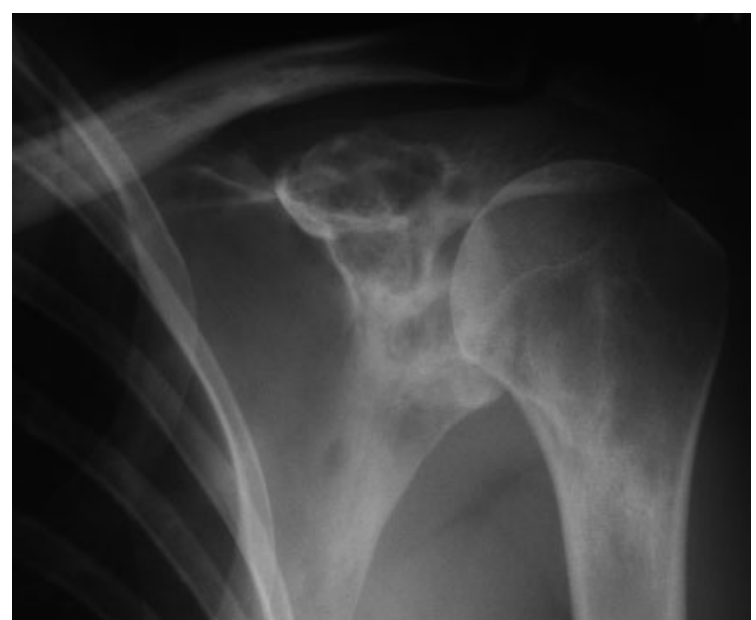

Figure 1. Lesion of the right shoulder at the age of 33 years. FD typical changes are notable.

The transformation of FD into osseous malignant tumors has been reported though the risk seems to be low. The most common entity of osseous neoplasm developing after FD are osteosarcomas while the development of MFH is rarely observed..$^{12}$

\section{CASE REPORT}

We report a case of a 37 year old female without significant personal (e.g. endocrine, dermal, neurological) or familiar medical history. Four years previous to the first presentation in our department, she complained of increasing pain in the right shoulder where radiologically a lesion was seen (Figure 1). Bioptically, no define histological diagnosis could be established.

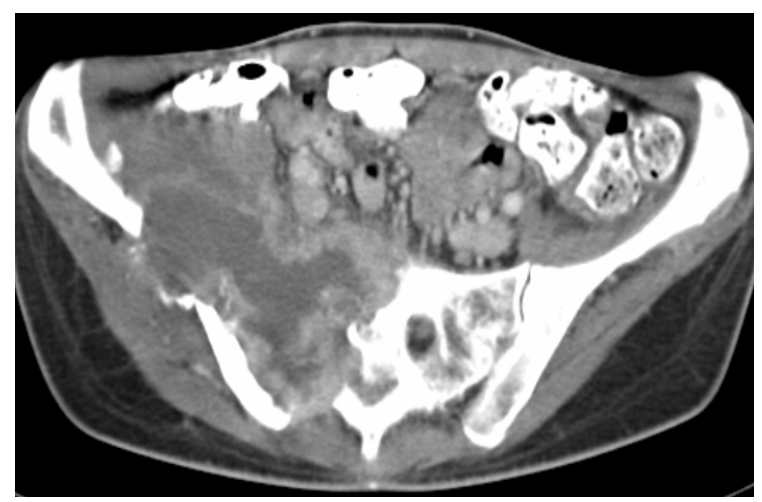

Figure 2. Infiltrative lesion of the os ischium and os sacrum with important soft tissue infiltration causing therapy-resistant pain and immobilization 


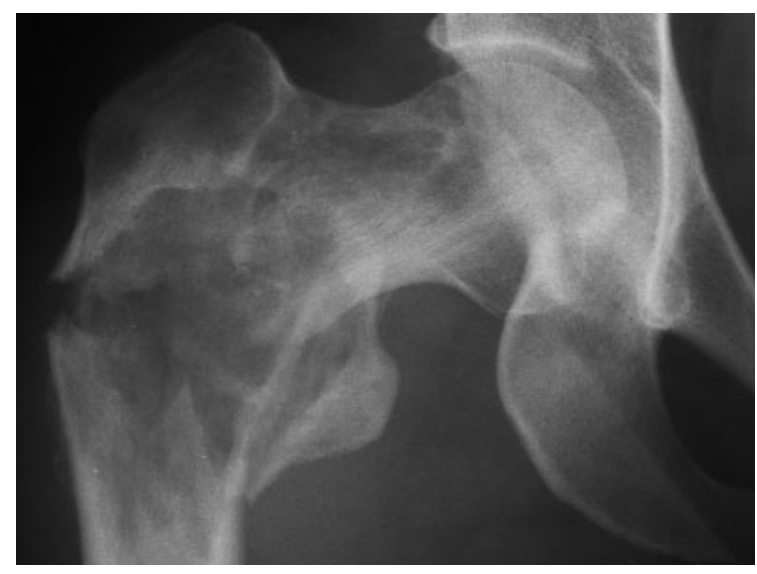

Figure 3. Pathologic fracture of the left femur leading to the diagnosis of MFH of the bone.

About three years thereafter, lumbalgia and paresthesia of the left thigh emerged. Multiple lesions of the right os ileum and os sacrum, the left proximal femur, the right scapula and the right proximal humerus were seen by conventional roentgen with the same characteristics as the above lesion. Biopsies of the os ileum and femur revealed no definite histological diagnosis. As no clinical, histological or radiological signs of malignancy were detectable, the diagnosis of FD was consequently established and oral bisphosphonates were administered. Though, pains were not relieved, interfered more and more with daily routine and finally rendered walking impossible. A MRT of the spine and a CT scan of the pelvis showed a lesion of the os ischium and os sacrum with important soft tissue infiltration measuring about 8-9 $\mathrm{cm}$ (Figure 2). During the work-up while hospitalized and bedfast, the patient suffered without an adequate trauma - a fracture of the left femur which required surgical therapy (Figure 3).

In this specimen and additional biopsies, the histological diagnosis was MFH of the bone with a highly malignant, dedifferentiated, spindle cellular part located in the right os ileum and the left proximal femur while a low malignant variant with partly storiform, partly inflammatory and giant cell histology could was found in the other biopsies. Immunohistochemically, the spindle cell variant of the tumor was focally positive for cytoplasmatic smooth muscle actin and vimentin and negative for desmin, pancytokeratine and LC and proliferation was focally up to $60 \%$ (Ki-67). In the revision of prior biopsies no

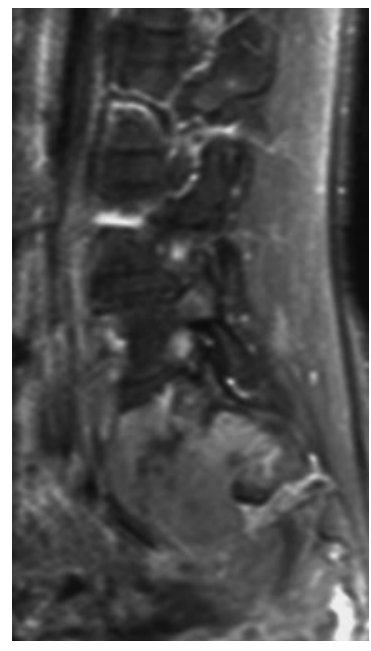

Figure 4. Signs of local progression with new infiltrations of neuroforamina S1 to S3 after chemotherapy according to the cOSs 96 protocol other diagnosis, e.g. a very well differentiated sarcoma, could be established.

A tumor typical metabolization was found with a FDG-PET scan in the right os ileum and neighbored bones, the left proximal femur, the right shoulder (humerus and scapula), in the processus spinosus of the 7th cervical vertebra and in the left paramedian mediastinum (not shown). Centrally in the larger tumor localizations (os ileum, femur), the lower glucose metabolization was interpreted as beginning spontaneous necrotization. An single metastasis in segment 8 of the liver was found.

In laboratory exams, a hypochrome, microcytic anemia was found, the C-reactive protein, the alkaline phosphatase and the alanine aminotransferase were elevated. Electrolytes including anorganic phosphate or tumor markers were normal.

\section{THERAPY, RESPONSE, RESTAGING}

Chemotherapy according to the COSS 96 (doxorubicine $90 \mathrm{mg} / \mathrm{m} 2,24 \mathrm{~h}$, day 1 , methotrexate 8000 $\mathrm{mg} / \mathrm{m}^{2}, 4 \mathrm{~h}$, day $21+28$ ) was administered. After ANC regeneration restaging by $\mathrm{CT}$ scan of the thorax, abdomen and pelvis revealed an increase of the initial lesion to $13.5 \times 10 \mathrm{~cm}$ and new infiltrations of the acetabulum and neuroforamina S1 to S3 were noted (Figure 4). Though the formerly described hepatic metastasis receded slightly, two new lesions in segment 7 were found. Additionally, a peritoneal metastasis $(5.2 \times 3.9 \mathrm{~cm})$, multiple renal metastases and spleen developed. 
The chemotherapy was therefore intensified with ifosfamide $\left(3000 \mathrm{mg} / \mathrm{m}^{2}\right.$, day $\left.1+2,28+29\right)$ and cisplatin $\left(120 \mathrm{mg} / \mathrm{m}^{2}\right.$, day $3 ; 40 \mathrm{mg} / \mathrm{m} 2$, day $\left.30-32\right)$. A partial response to this therapy was observed on day 21. The patient developed neurological symptoms during the sixth week and a cranial CT scan revealed a hypodense cerebral metastasis in the left frontoparietal region (not shown). With the cerebral metastasis evolving while under chemotherapy and the advanced stage, the patient chose to receive palliative care and deceased soon after.

\section{DISCUSSION}

We present a case of a multifocal MFH of the bone evolving from polyostotic FD in a young female. The first symptoms of FD became apparent the rather elevated age of 33 years. Though different bones of the trunk and extremities were involved in this case of polyostotic FD, no other signs or medical history of MAS could be detected. FD/MAS as a result of a mutated embryonic stem cell may present with a wide spectrum: from monostotic FD as one end to panostotic FD with involvement of multiple extrasceletal organs as the other extreme ${ }^{13}$ depending among others on the exact moment of mutation during embryogenesis.

Malignant transformation of FD is rare. Incidence rates vary. In a series of 1122 cases with FD reported by Ruggieri et $\mathrm{al}^{12}$ of the Mayo clinic only $2.5 \%$ of patients $(n=28)$ developed sarcomas - only one case of secondary with MFH - arising of the underlying disease. Most sarcomas arose in monostotic FD (19 of 28 cases) what reflects the relative frequency of $70 \%$ of monostotic forms. A history of prior radiation - a potential risk factor for malignant transformation - as therapy for the fibrous dysplasia was found in $46 \%$ of the patients. In another series of 72 patients with craniofacial FD only one patient developed a MFH in the observation period of 18 years. ${ }^{14}$

Histological differentiation was not homogeneous within the specimens of different localizations in this case. Together with the long history of disease it may be speculated that a underlying low grade tumor developing slowly in multiple localizations. Still, the mechanism of synchronous malignant transformation in distant sites is unknown. The highly malignant part of the tumor found in multiple localizations (os ileum, femur) probably developed rapidly before diagnosis and was determining the fate of the patient. It revealed inherent high resistance to chemotherapy and lead to a fast relapse.

This is to our knowledge the first report of a multifocal MFH of the bone arising from FD. Apart from case reports [e.g. 15-17], the above mentioned series ${ }^{12,14}$ and a more recent publication by Hoshi ${ }^{18}$ little is known about the malignant transformation of FD. A risk factor seems to be a history of prior radiation. The role of Gs alpha mutations in the pathogenesis of secondary malignancies after FD needs to be elucidated.

The treatment principles established for osseous tumors should be applied wherever possible. The clinical course of patients in comparison to others with sporadic osseous malignancies cannot be evaluated as no evidence based data is available due to the extreme rarity of the entity.

\section{REFERENCES}

1. Weinstein LS, Shenker A, Gejman PV, et al. Activating mutations of the stimulatory G protein in the McCuneAlbright syndrome. N Engl J Med 325: 1688-1695, 1991.

2. Marie PJ, de Pollak C, Chanson P, Lomri A. Increased proliferation of osteoblastic cells expressing the activating GS a mutation in monostotic and polyostotic fibrous dysplasia. Am J Pathol 150: 1059-1069, 1997.

3. Chapurlat RD, Meunier PJ. Fibrous dysplasia of bone. Baillieres Best Pract Res Clin Rheumatol 14: 385-398, 2000.

4. Schoenau E, Rauch F. Fibrous dysplasia. Horm Res 2002; 57 Suppl 2: 79-82.

5. Meister P. Malignant fibrous histiocytoma: histomorphological pattern or tumor type. Pathol Res Pract 192: 877-881, 1996.

6. Martignetti JA, Desnick RJ, Aliprandis E et al. Diaphyseal medullary stenosis with malignant fibrous histiocytoma: a hereditary bone dysplasia/cancer syndrome maps to 9p21-22. Am J Hum Genet 64: 801-807, 1999.

7. Link TM, Haeussler MD, Poppek $S$ et al. Malignant fibrous histiocytoma of bone: conventional X-ray and MR imaging features. Skeletal Radiol 27: 552-558, 1998.

8. Chen KT. Multiple fibroxanthosarcoma of bone. Cancer 42: 770-773, 1978. 
9. Finci R, Günhan O, Uçmakli E, Sarlak O. Multiple and familial malignant fibrous histiocytoma of bone. A report of two cases. J Bone Joint Surg Am 72: 295298, 1990.

10. Ozaki T, Taguchi K, Sugihara S, Inoue H. Multiple malignant fibrous histiocytoma of bone. A case report. Acta Orthop Scand 65: 209-211, 1994.

11. Maillefert JF, Guy F, Coudert B, et al. Multifocal malignant fibrous histiocytoma of the spine. Rev Rhum Engl. Ed 64: 274-277, 1997.

12. Rugiieri $\mathrm{P}, \mathrm{Sim} \mathrm{FH}$, Bond JR, Unni KK. Malignancies in fibrous dysplasia. Cancer 73: 1411-24, 1994.

13. Bianco P, Robey PG, Weintroub S. Fibrous dysplasia. In: Glorieux FH, Pettifor JM, Juppner H, eds. Pediatric Bone. San Diego, Ca, USA, Academic Press 2003: 509-539.

14. Cheng MH, Chen YR. Malignant fibrous histiocytoma degeneration in a patient with facial fibrous dysplasia. Ann Plast Surg 39: 638-642, 1997.

15. Ohmori $\mathrm{K}$, Matsui $\mathrm{H}$, Kanamori $\mathrm{M}$, et al. Malignant fibrous histiocytoma secondary to fibrous dysplasia. A case report. Int Orthop 20: 385-388, 1996.

16. Amin R, Ling R. Case report: malignant fibrous histiocytoma following radiation therapy of fibrous dysplasia. Br J Radiol 68: 1119-1122, 1995.

17. Ishida T, Machinami R, Kojima T, Kikuchi F. Malignant fibrous histiocytoma and osteosarcoma in association with fibrous dysplasia of bone. Report of three cases. Pathol Res Pract 188: 757-763, 1992.

18. Hoshi M, Matsumoto $S$, Manabe $J$ et al. Malignant change secondary to fibrous dysplasia. Int $\mathrm{J}$ Clin Oncol 11: 229-335, 2006.

\section{Correspondence}

Patrick BRÜCK

Medical Clinic for Hematology and Medical Oncology

University of Giessen

Klinikstrasse 36, 35392 Giessen,

GERMANY

Tel: (+49.641) 99-42651

Fax: (+49.641) 99-42659

e-mail: Patrick.Brueck@innere.med.uni-giessen.de 